\title{
COLLABORATION OF CLUSTERING TECHNIQUE AND PICTURE IN TEACHING VOCABULARY
}

\author{
Hidayatur Rohmah, Emi Lilawati \\ Universitas KH. A. Wahab Hasbullah \\ hidayaturrohmah@unwaha.ac.id
}

\begin{abstract}
This research was aimed to know the empirical evidence about the improvement of the students' English vocabulary through Clustering technique and picture as a media at the First Grade Students of Madrasah Mu'alliminn Mu'allimat Bahrul 'Ulum Tambakberas Jombang. The problem of the study was how to improve student's English vocabulary through Clustering Technique and Picture as a media. This pre-experimental research is quantitative and the data taken from the pre-test and post-test and test sheet is used as the instrumentation. The result showed that the use of clustering technique and picture as a media in teaching vocabulary mastery increased. It can be seen from the students' score of pre-test is 46.73 , meanwhile the mean score of post-test is 73.67 . The effectiveness of using this technique and media is implemented from students' scores which are increased after learning vocabulary by using collaboration between clustering technique and picture as a media.
\end{abstract}

Keywords: clustering technique; picture; vocabulary

\section{INTRODUCTION}

In learning English, mastering vocabulary can help to get easier to use a language as Norbert Schmitt (2000: 6) says that large vocabulary can help to express ideas precisely in communication. Vocabulary knowledge enables language use; language enables the increased of it, and knowledge of the world enables the increase of it and language use and so on. According to Linse and Nunan (2005:121) vocabulary is the collection of words that an individual knows. Meanwhile, Hiebert and Kamil (2005:3) states "vocabulary is the knowledge of meanings of words. Learning vocabulary is important as a part of learning English or other foreign languages since learners learn vocabulary first before they master more complex structure. So, one of the important components in teaching English besides grammar and pronunciation is vocabulary. We are unable to have a good listening, speaking, 
reading and writing without having great quantities of vocabulary.

Based on teaching experience at seventh grade, especially for VII-b, the researcher found that the students have difficulty and limit on vocabulary mastery. Most of the students have difficulties in studying English, they did not understand the meaning of words in English text. It was because they used dictionary in learning vocabulary. When the students found the difficulties in understanding the lesson, they tended to open their dictionary, so that the students forgot the meaning easily. Another problem was that they cannot make appropriate choice about what type of vocabulary learning strategy they should adopt in their learning process. This condition also happened because at VII-a grade, there were not English material. It means that for a year, they were not study English. It was the teacher's responsibility to help their students learn English language words efficiently.

Based on the statement of background and the researcher observation, the researcher intended to use Clustering technique for teaching vocabulary mastery. Frans (2004: 82) states that cluster is a technique that is made by the data analysis shaping, sorting our specialized in specific target based group, type. Clustering is a technique to divide some related ideas and write down in a blank of paper without evaluating the truth or value of the ideas themselves (Rico, 1983). Technique will be easier for the students to figure the meaning of the target word, to memorize it, and to use it when they find the right situation based on the context clues they have known (Surya, 2014: 3). Cluster technique is good way to turn a broad subject into a limited and more manageable way in teaching especially in teaching vocabulary.

According to the explanations above it can be put forth that clustering is a technique for developing the target words into new words related to them and put them into bubble diagram. Clustering technique seems to be important to find out the new words, so that they can recall and remind the vocabulary that they have learnt. By implementing clustering technique in learning the vocabulary, students can develop their vocabulary by clustering them with the linking word. Through clustering technique, the students are expected to be able to memorize and reproduces the words they have learnt easier than by memorizing through list of words based o0n the text book and they will be more interested in learning vocabulary so that their vocabulary skill will increase because there were different kind of teaching. In clustering technique, the students hold the main role on teaching learning process, the teacher just lead the students. The students are actively involved in the teaching learning process. Clustering technique uses a context clue that makes the students easier in learning vocabularies. Moreover, by using clustering technique, the student will also learn about the meaning of the words, the part of the speech of the words and try to use them in sentences orally.

Media is a tool that can be used to show something or object makes the students become more easily to know and understand what the object means. According to Hornby (2007: 953 ) media is the main ways that large numbers of people receive information and entertainment. In this case, there is 
a picture as media in teaching vocabulary. Sadiman et. al. (2010:29) mention one of the strengths of picture is that picture is concrete. Using pictures is useful for teaching vocabulary because it motivates students to learn English and the students were very enthusiastic in joining the teaching learning process (Aldhionita: 2015). Moreover, pictures are learning media that help teacher link between the materials taught to the students with the real situations and encourage students to make connection between the knowledge possessed and its application in their lives.

The objective of this study is expected to give practical contribution to the teaching of vocabulary, particularly at Madrasah Mu'allimin Mu'allimat Tambakberas Jombang, where the research is conducted. It is hoped that the use of clustering technique and picture as a media will be profitable source to the English teacher as a reference of using clustering technique and pictures to improve the students' vocabulary mastery skill and a valuable technique for teaching English to be applied in the classroom.

The study is pre-experimental research. Sukardi (2007) stated that pre-experimental research was the simple research that used singular variable used individual or group as object of study. This research is to know the implementation of cluster technique and pictures as a media in teaching vocabulary.

Population is the students of VII-B grade students of Madrasah Mu'allim Mu'allimat Tambakberas Jombang which consist of Class B1, B2, B3, B4 and $\mathrm{B} 5$. In this research, the researcher take the sample by using purposive sampling technique and the sample taken is VII-B3 class which has 38 students.
In order to get an enough data researcher will divide the test into two: pre-test and post-test. The purpose of giving the classroom tests was to measuring the skills, knowledge of intelligence, ability or talent possessed by individuals or groups (Arikunto, 2010, p.193). Technique of data collections is preparation and doing pre-test, treatment and post-test. After all completed, then data analysis is conducted and described it in order to get the purpose of this research based on the three topics of vocabulary, they are: classroom, bedroom, and bathroom.

\section{FINDINGS AND DISCUSSION}

During the teaching learning process, the students were asked to fill a bubble diagram from the core words given, the researcher asked them to make the cluster with three kinds of vocabulary in order to enrich their vocabulary skill. In a bubble diagram, they had to cluster/develop minimum eight words. Those eight words consist of noun. Most of them got difficulty in finding the vocabulary. Even though the students got some difficulties during the learning activities, they were interested in this technique and enthusiastic on the process of teaching learning English vocabulary through clustering technique and picture as a media. They also got higher score at the end of the last meeting of post-test.

Moreover, when clustering technique was used in the pre-experimental group, most of students felt happy and enjoyed in finding some vocabularies and pictures. Most all of the students are even more challenged to make a good cluster diagram and link the pictures from ideas in their mind. They were so busy at expressing, transferring, and associating their thoughts by using clustering technique and pictures. 
These are the main results as the finding of the research explained in several tables based on the topics. Based on the result of the data analysis, the researcher presents the discussion of the data analysis. Before giving treatment, most of the students' speaking skill was categorized fair, poor and very poor. It was proved by the percentage of total score of pretest.

\section{Pre-Test and Post-test Distribution Score based on Topic}

The following is the pre-test and post-test distribution score based on the three topics that conducted in this research about vocabulary mastery. The results are in tables and figure form.

\section{Topic 1 (Classroom)}

Table 1. The students' Score of Topic (1)

\begin{tabular}{|c|c|c|c|c|c|c|c|}
\hline \multirow{2}{*}{ No } & \multicolumn{3}{|c|}{ Pre-Test } & \multirow[b]{2}{*}{ Total } & \multicolumn{3}{|c|}{ Post-Test } \\
\hline & Item & $\begin{array}{c}\text { Correct } \\
(\%)\end{array}$ & $\begin{array}{l}\text { Incorrect } \\
(\%)\end{array}$ & & $\begin{array}{c}\text { Correct } \\
(\%)\end{array}$ & $\begin{array}{l}\text { Incorrect } \\
(\%)\end{array}$ & Total \\
\hline 1 & 1 & $19(50)$ & $19(50)$ & & 27 (71.05) & 11 (28.94) & \\
\hline 2 & 2 & $25(65.78)$ & $13(34.21)$ & & 28 (73.68) & $10(26.31)$ & \\
\hline 3 & 3 & $23(60.52)$ & $15(39.47)$ & & $28(60.52)$ & 15 (39.47) & \\
\hline 4 & 4 & $23(60.52)$ & $15(39.47)$ & & $30(78.94)$ & $8(21.05)$ & \\
\hline 5 & 5 & $26(68.42)$ & $12(31.57)$ & & $27(71.05)$ & 11 (28.94) & \\
\hline 6 & 6 & $17(44.73)$ & $21(55.26)$ & & 29 (76.31) & $9(23.68)$ & \\
\hline 7 & 7 & $20(52.63)$ & $18(47.36)$ & $57.51 \%$ & $25(65.78)$ & $13(34.21)$ & $71.04 \%$ \\
\hline
\end{tabular}

Based on the table above, the first topic of vocabulary that students learn is about things in the classroom is still low in the pre-test. Total percentage of the vocabulary is $57.51 \%$. The students still not comprehend yet about vocabulary things in the classroom. But, in the post-test, it can be seen that there is increasing score after students receive the treatment. The percentage is $71.04 \%$. It means there is an improving here although not too significant. It seems, the students have already familiar with the vocabulary, so from the pre-test they can reach the average more than an a half.

\section{Topic 2 (Bedroom)}

Table 2. The students' Score of Topic (2)

\begin{tabular}{|c|c|c|c|c|c|c|c|}
\hline \multirow{2}{*}{ No } & & \multicolumn{3}{|c|}{ Pre-Test } & \multicolumn{3}{|c|}{ Post-Test } \\
\hline & Item & Correct (\%) & $\begin{array}{c}\text { Incorrect } \\
(\%)\end{array}$ & Total & $\begin{array}{c}\text { Correct } \\
(\%)\end{array}$ & $\begin{array}{c}\text { Incorrect } \\
(\%)\end{array}$ & Total \\
\hline 1 & 1 & $11(28.94)$ & $27(71.05)$ & & $22(57.89)$ & $16(42.10)$ & \\
\hline 2 & 2 & $16(42.10)$ & $22(57.89)$ & & $29(76.31)$ & $9(23.68)$ & \\
\hline 3 & 3 & $18(47.36)$ & $20(52.63)$ & & 34 (89.47) & $4(10.52)$ & \\
\hline 4 & 4 & $13(10.52)$ & $25(65.78)$ & & $22(57.89)$ & $16(42.10)$ & \\
\hline 5 & 5 & $14(36.84)$ & $24(63.15)$ & & $25(65.78)$ & 13 (34.21) & \\
\hline 6 & 6 & $12(31.57)$ & $26(68.42)$ & & $23(60.52)$ & $14(36.84)$ & \\
\hline 7 & 7 & 15 (39.47) & $23(60.52)$ & $33.82 \%$ & $26(68.42)$ & 12 (31.57) & $68.04 \%$ \\
\hline
\end{tabular}

Based on the description above, it can be seen the percentage of students' score in the topic two is still low. Total percentage this topic is $33.82 \%$. The students still not understood yet about the vocabulary things in bedroom. But in the posttest, it can be seen that there is the effectiveness of using cluster technique with picture as a media in teaching vocabulary mastery in this topic. The total percentage of this indicator is increase from $33.82 \%$ to $68.04 \%$. 


\section{Topic 3 (Bathroom)}

Table 3. The students' Score of Topic (3)

\begin{tabular}{|c|c|c|c|c|c|c|c|}
\hline \multirow{2}{*}{ No } & \multicolumn{4}{|c|}{ Pre-Test } & \multicolumn{3}{|c|}{ Post-Test } \\
\hline & Item & $\begin{array}{c}\text { Correct } \\
(\%)\end{array}$ & $\begin{array}{c}\text { Incorrect } \\
(\%)\end{array}$ & Total & $\begin{array}{c}\text { Correct } \\
(\%)\end{array}$ & $\begin{array}{c}\text { Incorrect } \\
(\%)\end{array}$ & Total \\
\hline 1 & 1 & 18 (47.36) & $20(52.63)$ & & 32 (84.21) & $6(15.78)$ & \\
\hline 2 & 2 & $22(57.89)$ & $16(42.10)$ & & 31 (81.57) & $7(18.42)$ & \\
\hline 3 & 3 & 24 (63.15) & $14(36.84)$ & & $30(78.94))$ & $8(21.05)$ & \\
\hline 4 & 4 & $14(36.84)$ & $24(63.15)$ & & $32(84.21)$ & $6(15.78)$ & \\
\hline 5 & 5 & $19(50)$ & $19(50)$ & & 30 (78.94) & $8(21.05)$ & \\
\hline 6 & 6 & $18(47.36)$ & $20(52.63)$ & & $29(76.31)$ & $9(23.68)$ & \\
\hline 7 & 7 & $15(39.47)$ & $23(60.52)$ & $48.86 \%$ & $34(89.46)$ & $4(10.52)$ & $81.94 \%$ \\
\hline
\end{tabular}

So, in this topic, as seen in table 3 above, it can be seen there is significant improvement of students' score where the pre-test only $48.86 \%$ then after treatment improved become $81.94 \%$. This significant improvement is the implementation of using cluster technique with picture as a media in teaching vocabulary mastery to the students. They can suddenly remember the vocabulary. The improvement shows that the learning process had nearly covered the students' problem in their vocabulary achievement.

For comparison the percentage of topic of vocabulary mastery, before and after using cluster technique and picture as a media on teaching. It can be seen as follows.
Figure 1. the Comparison Percentage of Each Topic in Pre-test and Post-test

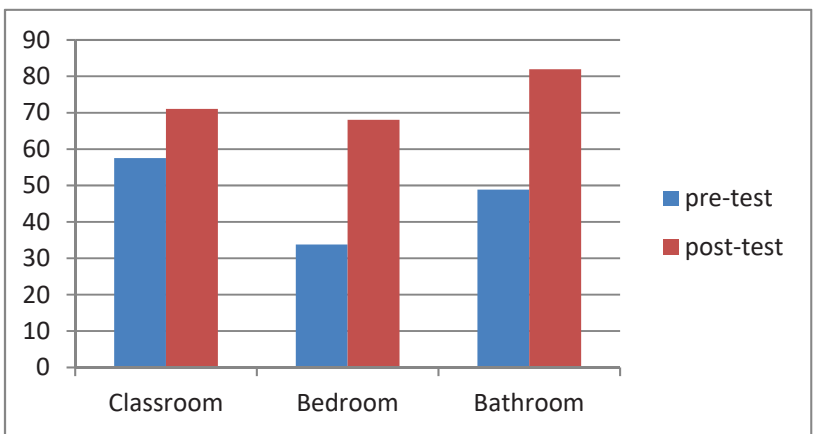

Based on the figure above, it can be seen the whole improvement of students' score. The difference between pre-test and post-test mean is 26.94. The difference between pre-test and post-test in topic 1 (classroom) is $13.53 \%$. The difference between pretest and post-test in topic 2 (bedroom) is 34.22\%. The difference between pre-test and post-test in topic 3 (bathroom) is $33.08 \%$.

From the figure also can be seen that total mean of pre-test is 46.73 and the total mean of post-test is 73.67 which is quite significant and effective. There is significant implementation that can be seen in the final sore of students. In other hand, the collaboration of clustering technique and picture as a media on teaching vocabulary are effective. It can be proved on pre-test and post-test. The diagram of cluster technique and picture as the interesting visual things for student can stimulate them to remember the vocabulary building deals with things in the classroom, bedroom, and bathroom that has been the topic in this research, diagram and picture of activity that occur in the treatment is succeed to attract the students become more active and understand the tense material easily instead of just remembering 
the vocabulary. Moreover, they can easily improve their vocabulary mastery by seeing the diagram and picture.

\section{CONCLUSION}

The main concern in this pre-experimental research is the discussion of any collaboration of using clustering technique and picture as a media on teaching vocabulary at seventh grade students of Madrasah Mu'allimin Mu'allimat Bahrul 'Ulum Tambakberas Jombang.

Based on the research findings, it can be concluded that Teaching English vocabulary for students by using clustering technique and picture as a media is effective. The diagram of cluster technique and pictures can increase the students' achievement in vocabulary. This finding may have been influenced by some particular factors that have been experienced by the students. Therefore, they finally feel the same level of anxiety in language learning.

\section{ACKNOWLEDGEMENT}

The researcher very pleased to say thank you to RISTEKDIKTI for giving chance to this research.

\section{REFERENCES}

Aldhionita, Lisa. (2015). A Study on Teaching Vocabulary using Pictures to the Second Grade Students at SMP MuhammadiyahKediri AcademicYear 2014/2015. Kediri: Universitas Nusantara PGRI Kediri.

Arikunto, S. (2013). Prosedur Penelitian Suatu Pendekatan Praktek. Jakarta: PT. Rineka Cipta

Frans M. Royan. (2004). Cluster strategy. Jakarta: PT Gramedia Pustaka Utama.

Hiebert, H. E. \& Kamil, L. M. (2005). Teaching and learning vocabulary: Bringing research to practice. New Jersey: Lawrence Erlbaum Associates Publishers.

Hornby, A. S. (2007). Oxford Advanced Learner's Dictionary. New York : Oxford University Press.

Linse, T. C. \& Nunan, D. (2005). Practical English language teaching: young learners. USA: McGraw-Hill Companies.

Rico, Gabrielle Luser. 1983. Writing the Natural Ways: Turn the Task of Writing into the Joy of Writing. (online), http://www.gabrielerico.com/Main/ AboutGabrieleRico.htm, accessed on 4 June 2019

Sadiman, Arief S. et. Al. (2010). Media Pendidikan: Pengertian, Pengembangan, dan Pemanfaatannya. Jakarta: Rajawali Pers.

Schmit, Norbert. (2000). Vocabulary in Language Teaching, New york: Cambridge University press.

Sukardi. (2007). Metodologi Penelitian Pendidikan; Kompetensi dan Praktiknya. Jakarta: Bumi Aksara

Surya, Dian. (2014). Improving Students' English Vocabulary Through Cluster Technique (A Classroom Action Research at the Second Grade of SMP AlKautsar BKUI Jakarta). Jakarta: Universitas Syarif Hidayatullah. 